\title{
The influence of parenting styles and thematic learning on the ethical relationship of Buddhist Sunday School students
}

\author{
Meto Sarono ${ }^{*}$ \\ 1Department of Buddhist Education, Smaratungga Buddhist College, Boyolali, Indonesia
}

\section{ABSTRACT}

The aims of this research are that to determine the influence of parenting styles and thematic learning on the ethical relationship of Buddhist Sunday School students. Employing correlational qualitative research, this research was conducted at the Vihara Dewi Kwan Im Kayong Utara Buddhist Sunday School with 25 samples aged 12-18 years old. Determination of the sample in this study using non-probability sampling with saturated sample technique because the number of samples is below 30. Data collection is done by using a questionnaire technique. The collected data were analyzed sequentially with the prerequisite test for data analysis, descriptive analysis, classical assumption test, multiple linear regression test and effective contribution analysis. The results of the study show that: (1) parenting style has an influence on the ethical relationship of Buddhist Sunday School students with a significance of 0.004 and a $t_{\text {count }}$ of 3.269 and is effective at $27.8 \%$; (2) thematic learning on friendship has an influence on the ethical relationship of students with a significance of 0.015 and $t_{\text {count }}$ of 2.642 and effective reaching $18.9 \%$; and (3) parenting style and thematic learning on friendship simultaneously have an influence on the ethical relationship with a significance of 0.001 and $F_{\text {count }}$ of 9,645 and R2 of $46.7 \%$, which means that they are in the sufficient category. Based on the results of this study, the contributions of this study are to give beneficial awareness of appropriate parenting styles and the thematic learning on the ethical relationship for teenagers.

\section{ARTICLE INFO}

\section{Keywords:}

parenting style, thematic

learning, ethical

relationship

\section{Article History:}

Received : June $17^{\text {th }}, 2021$

Revised : June $22^{\text {nd }}, 2021$

Accepted : June 23rd, 2021

Published : June $28^{\text {th }}, 2021$

How to Cite in APA Style:

Sarono, M. (2021). The influence of parenting styles and thematic learning on the ethical relationship of Buddhist Sunday School students. Smaratungga: Journal of Education and Buddhist Studies, 1(1), 12-28.

\section{Introduction}

Adolescence is identical with behavioral changes, both physically and mentally. Mental and physical behavioral changes have major impacts on both personal and social aspects. The impact can be positive or negative. Adolescence is understood as a turning point in the life cycle, a stage when a person begins not only to make personal decisions, but also to develop an identity for oneself (Alonso-Stuyck, 2019). There are phenomena among adolescent students, such as bullying, hate speech, sexual harassment and other negative things show that today's adolescents are experiencing a character crisis. The contributing factors are the patterns of interaction, social patterns, and the dynamics of contemporary social life which

\footnotetext{
*Corresponding author: mettodejavu@gmail.com Published by Center of Research and Publication of Smaratungga Buddhist Collage

This is an open access article under the CC BY-NC 4.0 (https://creativecommons.org/licenses/by-nc/4.0/)
} 
tend to ignore values, norms, morals, and character. Changes in behavior will cause rampant immoral acts in society or often called demoralization (Sulton, 2016).

The real result of demoralization is the rampant delinquency of adolescent students. The phenomenon of juvenile student's delinquency is influenced by low ethics. Ethics greatly influences human life. Ethics will influence human actions because they play a role in helping humans to decide what to do and what to avoid. All aspects of human life will be colored by their ethics (Barnawi \& Arifin, 2012).

There are two factors that could give an impact on adolescents ethics, which are family life in accordance with parenting styles and friendship. Family is the first and foremost educational institution for a child, and parents are the first teachers. The main obligation of Buddhist parents in raising children is to prevent their children from doing bad things, encouraging children to do good, providing good education, encouraging to find good friends and partners, so that in the end a child deserves to inherit from the parents (D.III.189).

Therefore, it can be said that parenting is a process of interaction between parents and children, which includes activities such as nurturing, educating, guiding and disciplining in reaching the maturity process, either directly or indirectly. Parenting is nothing but the method or way chosen by educators in educating their children which includes how educators treat their students (Gunarsa \& Gunarsa, 2012). There are several parenting styles, namely permissive, authoritarian and democratic (Baumrind, 1966). Permissive parenting describes the conditions in which parents give freedom to children to act according to their wishes, and what children do without parental supervision, so that parents never know whether what the child is doing is right or wrong. This is different in authoritarian parenting. In this parenting style, everything the child will do must have the consent of the parents. Children should not argue with what their parents say and the freedom of children is shackling. Meanwhile, democratic parenting is the combination of permissive parenting and authoritarian parenting (Dariyo, 2011).

Another factor that influences the social ethics of students is friendship. Friendship is a process of interaction carried out by individuals with individuals, or individuals with groups. Parenting is applied by parents in the family environment, while student friendships are established in the school environment. To interpret friendship, it is necessary to have guidance, especially in the Buddhist Sunday school environment so that students can interpret the meaning of good friendship.

The Buddhist Sunday School, as a non-formal education institution, has a strategic role to contribute to ethical education for adolescents. The orientation in the Buddhist Sunday School curriculum is holistic thematic. The holistic goals to be achieved are physical development (kāya bhāvanā), social and moral development (sīla bhāvanā), mental development (citta bhāvanā) and wisdom development ( $p \bar{a} \tilde{n} \tilde{n} \bar{a}$ bhāvanā). An appropriate theme for developing the social ethics of teenage students is the theme of friendship.

Learning the theme of friendship will encourage students to develop ethical relationships with fellow students physically, socially, mentally and wisely. Friendship in question is positive friendship with good friends (kalyāna mitta) so that it brings positive impact and is not detrimental, because being friends with 
good people is a blessing of glory (Khp. 5; Sn. 259). Meanwhile, making friends with those who are not good is the source of collapse (Sn.94).

The Buddhist Sunday School of Vihara Dewi Kwan Im, North Kayong is dominated by teenage students. There are phenomena in regard to students' unethical behavior at Vihara Dewi Kwan Im of North Kayong, such as lack of discipline, disrespect, lack of tolerance, habits of mocking friends, hate speech, wearing unappropriated clothes, playing mobile phones while praying, calling friend's names in improper ways, disturbing friends, and so on. These phenomena can be considered normal if it occurs to students when they enter adolescence, but if there is no guidance and direction it can bring a negative impact on themselves, others and the environment.

Parenting styles and thematic learning on friendship in the Buddhist Sunday School are assumed to have a positive influence on the social ethics of students. To find out the extent of the influence of parenting styles and thematic learning in the Buddhist Sunday School, it is necessary to conduct research. Therefore, the aims of this research are to describe the influence of parenting styles and thematic learning on the ethical relationship of Vihara Dewi Kwan Im Buddhist Sunday Schools Students of Kayong Utara.

\section{Student Social Ethics}

Etymologically, the word "ethics" comes from Greek which consists of two words, namely ethos and ethikos. Ethos means nature, habitual character, ordinary place. Ethikos means morality, civility, behavior and good deeds (Bagus, 2000). According to the Great Dictionary of Indonesian Language, ethics is the science of what is good and what is bad and about moral rights and obligations. Ethics are values and moral norms that are used as a guidance by a person or group in regulating their behavior (Bertens, 2002). The term ethics is often equated with morals. The term moral comes from the Latin word mores, which is the plural form of mos, which means customs or habits of character, behavior, character, and way of life (Bagus, 2000). Although etymologically the meaning of the words ethics and morals have the same meaning, they are not exactly the same as morality. Ethics is a kind of reviewer on the activities of everyday human life, while morality is an assesor to assess whether it is true or not. If the notions of ethics and morals are connected to one another, it can be interpreted that ethics and morals have the same object, that both are discussing human actions to determine their good or bad positions.

Ethics in the context of Buddhism is called silla, which are defined as (1) nature, character, disposition, habits, and behavior. Sīla is more often an adjective, for example good behavior (susīla), bad behavior (dussīla), stingy nature (adanasīla), noble character (parisudhasila); and (2) moral training, moral practice, good behavior, ethics, morals. Sila was first taught by the Buddha to the five ascetics as an aspect of the path leading to the cessation of suffering (S.V.420). Silla has the characteristic of steady-calm (sillana), which is in harmony with control, keeping one's bodily actions and speech in harmony. A person who practices the precepts keeps his behavior steady and his physical and verbal actions are not wild, but in a controlled manner. Precepts have a function in two aspects: serves as action (kiccarasa) and serves as achievement (sampattirasa). 
Silla functions to get rid of unwholesome actions (dussīla) as an act and has the nature of blameless as its attainment. Silla has purity as its manifestation, namely: purity of body, purity of speech, and purity of mind. Silla is manifested or understood as a pure quality. The closest cause, sīla means ashamed of doing evil or moral that is ashamed of doing evil (hirī) and moral which is afraid of doing evil (ottappa). A person can maintain pure precepts only if he has a moral shame that is ashamed of doing evil and a moral that is afraid of doing evil. Sīla produces many benefits starting with purity of mind and regretless. Silla has purity, tranquility and inner peace as benefits; sila has the ability to purify and invigorate the mind (Vism.10). One who practices the precepts well, his fragrant name is widespread as far as the realm of the gods; obtains physical and mental wealth; without fear and doubt in association with others; praised by the wise; dies peacefully; and reborns in the heavenly realm (D.II.87). One should perfect the practice of precepts, if one hopes to gain the respect and favor of one's peers (M.I.33). Sïla plays a very big role in the association, especially the association of students.

According to Endraswara, in daily interactions at school students should: (1) greet their friends, teachers, school principals and school employees when they meet in the morning, during the day and or will separate in the afternoon and evening. Carry out good habits, such as greet, smile, shake hand, polite and courtesy; (2) respecting fellow students, cherishing each other, respecting differences in religion and socio-cultural background that each friend has, both at school and outside of school; (3) respecting the ideas, thoughts and opinions, copyrights of others and property rights of friends and school members; (4) dare to say wrong to something that is wrong and stating true to something that is true; (5) express opinions politely and do not offend others; (6) make it a habit of saying thank you when getting help or services from other people; (7) dare to admit mistakes that have already been done and apologize if they feel they have violated the rights of others or have wronged others; and (8) use polite and respectful language (words) that differentiate relationships with others who are older and peers, and do not use profanity and harsh words, insults and pornography (Endraswara, 2010).

According to Sarumpaet, there are things that can be done and shouldn't be done, namely: (1) do not criticize other people's conversations, so that people are happy, need to be a good listener, pay attention to other people's conversations; (2) talk about things that are pleasing to others, in order to build friendships; (3) knowing other people's names, this gives the impression of being a caring person; (4) friendly and cheerful, someone needs to try to be friendly and likes to smile in social interactions; (5) being honest that being in the association, each person must act as honestly as possible. Trying to honestly address the shortcomings of friends but with reason and courtesy; and (6) trying to help, trying to help each other, offer help to reduce or solve problem or other's work (Sarumpaet, 2006)

Association in the Buddhist concept corresponds to the term sevana; bhajana; payirupāsana. saṃsagga; santhava; sanggama; saṃsada, sabhā; samiti, sangama; samsada; samājāyatta (Buddhadatta, 1989). Meanwhile, the equivalent terms with the word friend include: mitta; sakha; sahāya; suhada, samma (Buddhadatta, 1989). Broadly speaking, there are several actions that are manifestations of social attitudes. These actions include approaching or 
approaching (upasan்kamana), close friendships (payirupāsana), liking (sampiya), being loyal to them (bhatti), exchanging thoughts and views (Sanditțha), staying and eating together (sambhatta), imitating (ditthanugati). Of all the manifestations of a social definition, showing example is the most important thing.

Friendship (mittatā or sakkhī) is a close relationship between two or more people who are loving and non-sexual. Friendship is also defined as a model of social harmony in the worldly sphere and a model of spiritual encouragement by monks who transcend the worldly sphere (Harvey, 2000). Meanwhile, according to the Encyclopaedia of Buddhism, friendship is a mutual attachment, affection, or deep thing that exists between two or more people, which is different from sexual or family attachment. It is a reciprocal relationship and forms an important element in every society, although it is not generally considered an inseparable condition of life (Malalasekera, 1990).

Good association can support the progress of mindset and other development. Through friends or good friends, one can try to mature a mindset that leads to wisdom. The significance of the relationship is as a first step to rely on in finding inspiration, ideas, views, character, understanding, and motivation. One of the factors that determine a person's character is association. Like what kind of association a person has, it will give a picture of the quality of one's life. The quality of one's life is very much dependent on the quality of one's relationships with the people around them. What kind of people does he make friends with, whom he associates with, his qualities will be the same as those of his friends. Like wrapping a rotten fish in leaves, the leaves also smell bad, on the other hand, wrapping incense sticks in leaves, the leaves will also smell good (It.68-69).

Based on the literature that has been described, it is concluded that the social ethics of students in this study is the implementation of good behavior guidelines in interactions between students in the Buddhist Sunday school environment. The Buddha taught about things that can support a good relationship or an atmosphere of friendship (sanghāvatthu) as social ethics, namely generosity (dāna), courtesy (piyavācā), willing to help (atthacariyā) and not discriminating (samānattatā) (A.II.32). The four values are developed to become indicators of the social ethics of students in this study, namely courtesy, honesty, respect and generosity.

\section{Parenting}

Parenting is a set of parental attitudes towards children which are communicated to the child and create an emotional atmosphere in which parental behavior is expressed (Darling \& Steindberg, 1993). Parenting is nothing but the method or method chosen by educators in educating their children which includes how educators treat their students. The party that is meant by educators is parents, especially fathers and mothers or guardians (Gunarsa \& Gunarsa, 2012). In principle, parenting is parental control, namely how parents control, guide and accompany their children to carry out their developmental tasks towards the maturation process (Baumrind, 1966). Parenting style is a description of the attitudes and behavior of parents towards their children (Djamarah, 2014). Parenting is the nurture or implementation of a series of decisions made by 
parents or adults to their children so as to allow their children to be responsible, become good members of society, and have good character (Sunarti, 2004).

Based on the description above, it can be concluded that parenting is a process of interaction between parents and children, which includes activities such as nurturing, educating, guiding and disciplining in achieving the maturity process, either directly or indirectly. That the purpose of parenting is to build positive relationships with the children in the family to ensure their development and wellbeing (Lorence, 2019).

Parenting in the context of Buddhism is a relationship of interaction responbility between parents and children. Buddha pointed out what duties parents should carry out to their children and vice versa. The obligations of parents towards children taught by the Buddha are as follows: (1) to prevent children from doing bad things; (2) encouraging children to do good; (3) provide professional education to children; (4) ensuring a suitable partner for the child; and (5) hand over the inheritance to the child at the right time (D. III. 189). The application of parenting in the context of Buddhism that parents should be able to become true friends (kalyānamitta) for their children in accompanying their growth and development process so that they can internalize Buddhist values in themselves (Sulaiman, 2018).

The parenting style adopted in this study is the parenting style according to Baumrind which was adapted by Stewart and Koch (1983), namely authoritarian parenting, democratic parenting and permissive parenting.(Stewart \& Koch, 1983). (1) Authoritarian parenting (parent oriented). This parenting characteristic emphasizes that all parents' rules must be obeyed by the child. Parents act arbitrarily, without the child's control. Children must obey and must not argue against what is ordered by the parents; (2) Permissive parenting style (children centered). The nature of permissive parenting is that all family rules and regulations are in the hands of the child. What the children do is allowed by the parents, the parents obey all the wishes of the child; (3) Democratic parenting, the position between children and parents is equal. A decision is taken jointly by considering both parties. Children are given responsible freedom, meaning that what the children do must still be under the supervision of their parents and can be morally responsible.

\section{Buddhist Sunday School Curriculum}

The Buddhist Sunday School curriculum takes the form of thematic learning development. Thematic learning is learning that departs from a certain theme as a center that is used to understand the symptoms and concepts both from the field of study concerned and from other fields of study (Madjid, 2014). In essence, the Buddhist Sunday School learning process is actually to recognize the sublime teachings of Buddha which can be applied contextually in everyday life. This is a foundation that must be filled in the stages of child development. Its application must pay attention to the characteristics of student's learning. After attending Buddhist Sunday School, the study continued with the Buddhist habit styles at home together with parents (Solomon, 2019). The formulations of the core competencies in the Buddhist Sunday School education are as follows: (a) physical development (kāya bhāvanā), showing what is known, felt, needed, and thought 
through the five senses and works productively and creatively and reflects the behavior of Buddhist character; (b) social development (sīla bhāvanā), having honest behavior, discipline, care, respect, tolerance, conformity, responsibility, humility, politeness in interacting in the family environment, Buddhist Sunday School, wihara, and society; (c) mental development (citta bhāvanā), having the ability to resist negative impulses and wholesome desires for truth, kindness, patience, endurance and a sense of humor, practice meditation for mindfulness, inner peace and clarity of mind, development of loving kindness and compassion; and (d) wisdom development (pañ ñ̄ bhāvanā), having the ability to think creatively, constructively, and the ability to interpret learning experiences at home and the Buddhist Sunday School environment by seeing directly and as it is. Based on Core Competencies, Basic Competencies and Themes lead to a holistic goal as the pinnacle of learning achievement (Drafting Team, 2017). The holistic development model for the theme of friendship is as shown in the following table:

Table 1. Thematic Friendship

\begin{tabular}{|c|c|c|c|c|}
\hline $\begin{array}{l}\text { Physical } \\
\text { Development } \\
\text { (Kāya } \\
\text { Bhāvanā) }\end{array}$ & $\begin{array}{l}\text { Development } \\
\text { Social } \\
\text { (Sïla Bhāvanā) }\end{array}$ & $\begin{array}{l}\text { Development } \\
\text { Mental } \\
\text { (Citta } \\
\text { Bhāvanā) }\end{array}$ & $\begin{array}{l}\text { Development } \\
\text { Knowledge } \\
\text { (Pan̄̄na } \\
\text { Bhāvanā) }\end{array}$ & Learning Themes \\
\hline $\begin{array}{l}\text { KD } \\
\text { Apply } \\
\text { good } \\
\text { friendship in } \\
\text { everyday life }\end{array}$ & $\begin{array}{l}\text { KD } \\
\text { Behave } \\
\text { politely, } \\
\text { appreciative, } \\
\text { and tolerant in } \\
\text { friendships }\end{array}$ & $\begin{array}{l}\text { KD } \\
\text { Develop } \\
\text { loving } \\
\text { kindness and } \\
\text { affection in } \\
\text { friendshp }\end{array}$ & $\begin{array}{l}\text { KD } \\
\text { Have } \\
\text { ability } \\
\text { interpret } \\
\text { friendship }\end{array}$ & $\begin{array}{l}\text { Friendship } \\
\text { - Helping friends } \\
\text { - Friends during } \\
\text { happy and bad } \\
\text { times } \\
\text { - Friends who } \\
\text { give good advice } \\
\text { - Friends who are } \\
\text { symphathetic }\end{array}$ \\
\hline
\end{tabular}

(Source: Buddhist Sunday School Thematic Curriculum, 2017)

\section{Method}

This research is a correlational quantitative research. Correlational research involves collecting data to determine whether and to what extent a quantitative relationship exists between two or more variables. According to Gay, correlational research is sometimes treated as descriptive research, mainly because correlational research describes existing conditions. However, it differs from the description of a report or observational study because in a correlational study the relationship of the variables is described quantitatively (Emzir, 2015).

\section{Research design}

There are various types of correlational research designs, and this study uses multiple regression designs. Multiple regression is an extension of simple regression and simple prediction with the addition of several variables. The combination of several variables gives more power to make accurate predictions (Emzir, 2015). 


\section{Participants}

The research was conducted at the Buddhist Sunday School of Vihara Dewi Kwan Im Kayong Utara with a sample of 25 adolescent students aged 12-18 year olds. Determination of the sample using non-probability sampling with saturated sample technique because the total sample is below 30 .

\section{Data collection}

Data collection was carried out by using a questionnaire technique. The questionnaire in this study was used to reveal the variables of parenting, thematic learning of friendship and variables of student social ethics. The questionnaire for parenting, thematic learning of friendship and the ethics of student interaction was compiled by researchers, consulted, tested, revised, re-tested and finally became a questionnaire that was ready to use.

\section{Data analysis}

The collected data were analyzed sequentially with the prerequisite test for data analysis, descriptive analysis, classical assumption test, multiple linear regression test and effective contribution analysis.

\section{Findings}

\section{Descriptive analysis}

Based on the research data of all parenting style variables, the highest score was 97 and the lowest score was 62, so the data range was 35 . The mean score of parenting was 83.08; the middle value (median) is 86 , the mode is 80 , and the standard deviation is 9.836 . The number of class intervals is determined by the Sturgess formula, namely $\mathrm{k}=1+3,3 \log \mathrm{n}, \mathrm{k}=1+4.62=5.62$ (rounded to 6 ).

Table 2. Distribution frequency parenting data

\begin{tabular}{llll}
\hline No. & Interval & Frequency $(\mathrm{F})$ & Percentage $(\%)$ \\
\hline 1. & $62-67$ & 2 & 8 \\
2. & $68-73$ & 3 & 12 \\
3. & $74-79$ & 2 & 8 \\
4. & $80-85$ & 5 & 20 \\
5. & $86-91$ & 8 & 32 \\
6. & $92-97$ & 5 & 20 \\
\multicolumn{2}{l}{ amount } & 25 & 100 \\
\hline
\end{tabular}

(Source: Results of data processing)

Based on the categorization of tendencies that have been calculated, the distribution of parenting styles can be made into a table of parenting categories.

Table 3. Categories of parenting trends

\begin{tabular}{lllll}
\hline No. & Score & Frequency & Relative Frequency $(\%)$ & Category \\
\hline 1. & $>88$ & 9 & 36 & High \\
2. & $56 \leq 88$ & 16 & 64 & Moderate
\end{tabular}




\begin{tabular}{llll}
$3 \quad<56$ & 0 & 0 & Low \\
\hline Amount & 25 & 100 &
\end{tabular}

(Source: Results of data processing)

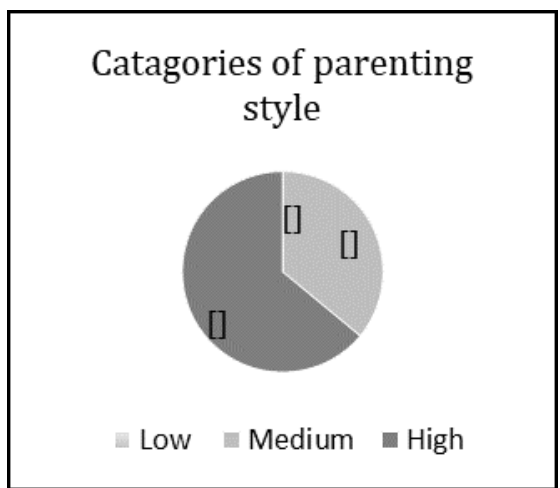

Figure 1. Categories of parenting style

Based on table 3 and Figure 1 mentioned above, it shows that most of the students got parenting in the medium category as many as 16 students (64\%), the rest were in the high category as many as 9 students (36\%) and the medium category and none were in the low category.

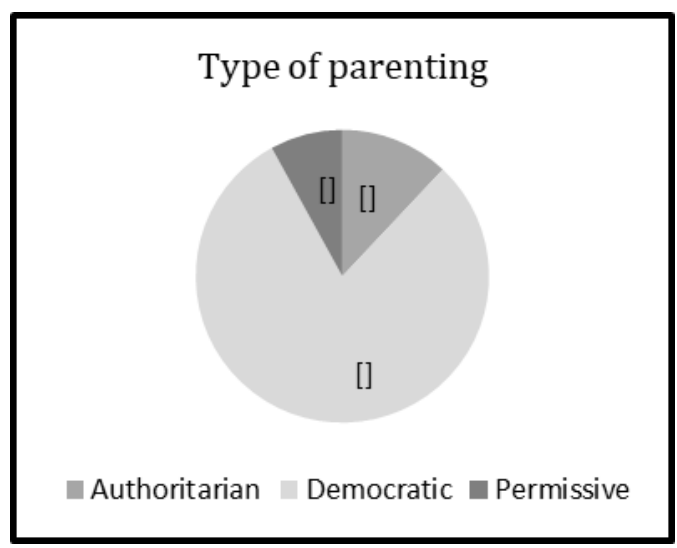

Figure 2. Types of parenting

Figure 2 shows that the parenting style for the authoritarian type is 3 students $(12 \%)$, democratic is 20 students $(80 \%)$ and permissive is 2 students $(8 \%)$.

Based on all research data on the thematic learning variable friendship processed with the help of the SPSS 21 application, the highest score was 104 and the lowest score was 86 , so that the data range was 18 . The average score (mean) of friendship thematic learning was 94.92; the middle value (median) is 95, the mode is 96 , and the standard deviation is 5.408. Number of class intervals 6 .

Table 4. Frequency distribution of friendship thematic learning data

\begin{tabular}{llll}
\hline No. & Interval & Frequency $(\mathrm{F})$ & Percentage $(\%)$ \\
\hline 1 & $86-88$ & 4 & 16 \\
2 & $89-91$ & 2 & 8 \\
3 & $92-94$ & 4 & 16 \\
4 & $95-97$ & 7 & 28
\end{tabular}




\begin{tabular}{llll}
5 & $98-100$ & 4 & 16 \\
6 & $101-103$ & 3 & 12 \\
7 & $104-106$ & 1 & 4 \\
\hline \multicolumn{2}{l}{ Amount } & 25 & 100 \\
\hline
\end{tabular}

(Source: Results of data processing)

Based onon categorization of trends that have been calculated, then the distribution of the thematic learning categories of friendship can be made a category table as follows:

Table 5. Categories of friendship thematic learning tendencies

\begin{tabular}{lllll}
\hline No. & Score & Frequency & $\begin{array}{l}\text { Relative Frequency } \\
(\%)\end{array}$ & Category \\
\hline 1 & $>88$ & 21 & 84 & High \\
2 & $56 \leq 88$ & 4 & 16 & Moderate \\
3 & $<56$ & 0 & 0 & Low \\
\hline \multicolumn{2}{l}{ Amount } & 25 & 100 & \\
\hline
\end{tabular}

(Source: Results of Data Processing)

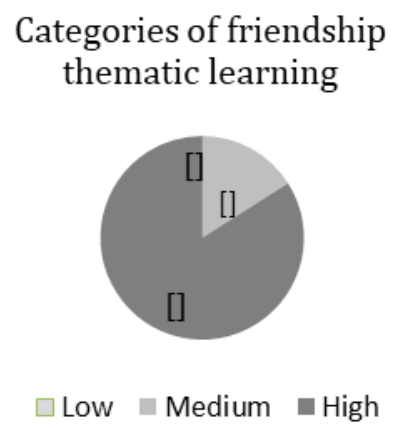

Figure 3. Categories of friendship thematic learning

Based on all research data on the variable of student social ethics score was the highest score of 87 and the lowest score was 64, so that the data range was 23 . The average score (mean) of friendship thematic learning was 76.64; the middle value (median) is 78, the mode is 78 , and the standard deviation is 6.297 and the number of class intervals is 6 .

Table 6. Frequency distribution of student social ethics data

\begin{tabular}{llll}
\hline No. & Interval & Frequency $(\mathrm{F})$ & Percentage $(\%)$ \\
\hline 1 & $64-67$ & 3 & 12 \\
2 & $68-91$ & 22 & 88 \\
\hline \multicolumn{2}{l}{ Amount } & 25 & 100 \\
\hline
\end{tabular}

(Source: Results of Data Processing)

Based on the categorization of tendencies that have been calculated, the distribution of the ethical categories of students' association can be made into a category table as follows: 
Table 7. Categories of social ethics tendencies of students

\begin{tabular}{lllll}
\hline No. & Score & Frequency & $\begin{array}{l}\text { Relative Frequency } \\
(\%)\end{array}$ & Category \\
\hline 1 & $>66$ & 22 & 88 & High \\
2 & $42 \leq 66$ & 3 & 12 & Moderate \\
3 & $<42$ & 0 & 0 & Low \\
\hline Amount & 25 & 100 & \\
\hline
\end{tabular}

(Source: Results of Data Processing)

Catagories of students social ethics

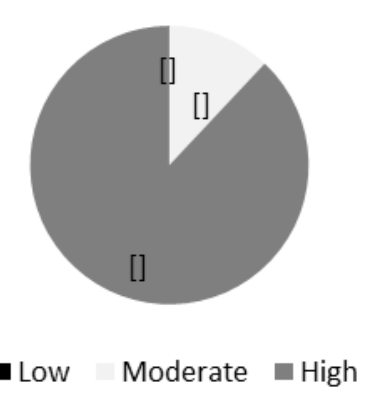

Figure 4. Categories of student social ethics

Based on table and the picture above shows that the social ethics of students in the high category are 22 students $(88 \%)$ and the moderate category is 3 students $(12 \%)$.

\section{Hypothesis test}

Hypothesis testing done in two stages, namely partial hypothesis testing (hypotheses 1 and 2) with t test and simultaneous hypothesis testing (hypothesis 3 ) with the $\mathrm{F}$ test based on the results of multiple linear regression analysis.

1. First Hypothesis Test:

Based on the test results of multiple linear regression, it can be seen that the significance of $\mathrm{X} 1$ is 0.004 and tcount is 3.268 . Based on the significance value, the value of $0.004<0.05$ means that the significance value is smaller than the probability value so that it can be concluded that $\mathrm{HO}$ is rejected and $\mathrm{Ha}$ is accepted. To find out the value of $t$ table, the formula $\alpha / 2$ is used; nk-1. 0.05 / $2 ; 25-2-1=0.025 ; 23=2,069$. Based on tcount, it is known that $3,268>2,069$ so it can be concluded that $\mathrm{H} 0$ is rejected and $\mathrm{Ha}$ is accepted. This means that there is an influence of parenting on the social ethics of students at Vihara Dewi Kwan Im Kayong Utara High School in 2020.

2. Second Hypothesis Test:

Based on the multiple regression test, it is known that the significance value of $\mathrm{X} 2$ is $0.015<0.05$, so it can be concluded that $\mathrm{H} 0$ is rejected and Ha is accepted. Meanwhile, based on tcount 2.642> 2.069, it means that $\mathrm{HO}$ is rejected and $\mathrm{Ha}$ is accepted. It can be concluded that there is an effect of friendship thematic learning on the social ethics of year 2020 BUDDHIST SUNDAY SCHOOL Vihara Dewi Kwan Im students. 
3. Third Hypothesis Test:

Based on the results of multiple linear regression, it is known that Fcount is 9.645. In this study, the F test was obtained through the comparison of Fcount and Ftable with a significance level of $5 \%$ and N 25, obtained Ftable was 3.44 using a confidence level of 95\%, $\alpha=5 \%$, df (N1) (number of variables -1 ) or $3-1$ $=2$, and df $2(\mathrm{~N} 2)=\mathrm{n}-\mathrm{k}$ or $25-3=22$ ( $\mathrm{n}$ is the number of respondents and $\mathrm{k}$ is the number of variables). The result obtained from Ftable is 3.44.

This shows that Fcount (9.645)> Ftable (3.44) and a significance level of 0.001 $<0.05$. This means that the significance value obtained is smaller than the assigned $\alpha$ probability $(0.001<0.05)$. So H0 is rejected and Ha is accepted. When viewed from the comparison between the value of Fcount and Ftable, the test results show a positive effect. Therefore, it can be concluded from the results of these tests that the variables of parenting and thematic learning of friendship together (simultaneously) have a positive effect on the social ethics of the students of Buddhist Sunday School of Vihara Dewi Kwan Im Kayong Utara in 2020.

\section{The influence of parenting styles on social ethics of students at vihara dewi kwan im kayong utara high school in 2020}

Based on the results of multiple linear regression, it can be seen that the significance of X1 is 0.004 and tcount is 3.268. Based on the significance value, the value obtained of $0.004<0.05$ means that the significance value is smaller than the probability value so that it can be concluded that $\mathrm{HO}$ is rejected and $\mathrm{Ha}$ is accepted. Meanwhile, based on tcount, it is known that 3.268> 2.07387 so it can be concluded that $\mathrm{H}_{0}$ is rejected and $\mathrm{H}_{a}$ is accepted. This means that there is an influence of parenting styles on the social ethics of students at Vihara Dewi Kwan Im Kayong Utara High School in 2020 and the results of the calculation of effective donations reached $27.8 \%$.

Result the according to research conducted by Marzuki and Feriandi (2016) which concluded that parenting has a positive influence on student moral action, with an effective contribution of 27.1\% (Feriandi \& Marzuki, 2016). Research by Siti Muhayati and Diana Ariswanti Triningtyas (2016) which concluded that parenting has an influence on the compliance of Cendikia Madiun School students in developing ethics or morality through the practice of fasting (Triningtyas, Muhayati, \& Ariswati, 2016). The results of other research conducted by Susanto and Aman (2016) has with the conclusion that parenting has an effect of $16.30 \%$ on the character of students of SMP Negeri 25 Purworejo.(Susanto \& Aman, 2016).

While (Sartika \& Daulay, 2014) points that bivariate statistical analysis obtained shows that there is a significant relationship between two parenting styles, namely authoritarian parenting types with adolescent socialization development $(\mathrm{p}$ value $=0.032)$ and democratic parenting style with adolescent socialization development ( $\mathrm{p}$ value $=0.000$ ). Research done by Raxsa, Yatno and Wardani (2018) about the influence of the social environment and parenting styles on the moral of Buddhist adolescents in Ponggok subdistrict, Blitar regency, concluded that parenting has an influence on adolescent morale by $0.170(17 \%)$. Another study was conducted on 296 adolescents in grades 7-11 in the country of Oman by (Alhadabi, 2019) states that the Path Analysis results show that the three 
parenting styles have a direct association with moral intelligence. This means that parenting affects students' morality.

\section{The influence of thematic learning of friendship on social ethics of students at Vihara Dewi Kwan Im of North Kayong High School in 2020}

Based on Multiple regression test, it is known that the significance value of $\mathrm{X}_{2}$ is $0.015<0.05$, so it can be concluded that $H_{0}$ is rejected and $H_{a}$ is accepted. Meanwhile, based on $t_{\text {count }} 2.642>2.07387$, it means that $H_{o}$ is rejected and $H_{a}$ is accepted. Based on this value, it can be concluded that there is an effect of thematic learning on friendship on students' social ethics. Based on the analysis of the effective contribution, the effect of friendship thematic learning on the social ethics of students at Vihara Dewi Kwan Im of North Kayong High School in 2020 with the calculation of the effective contribution reached $18.9 \%$.

The thematic variable of friendship tested in this study is more related to similar aged peer relationships because the research subjects have a peer age range and are classified as adolescents, namely 12-18 year olds. The test results in this study are in accordance with the research conducted by Susanto and Aman (2016) with the conclusion that similar aged peer interaction has an effect of $70.04 \%$ on the character of the students of SMP Negeri 25 Purworejo. Descriptive research by Umar and Hidayanti (2014) at SMP Negeri 5 Pare-pare concluded that the role of peer with similar age's association has a positive impact on the formation of student's ethics.

The influence of parenting styles and thematic learning on the ethical relationship of students at vihara dewi kwan im of kayong utara high school in 2020

Based on the simultaneous test $\left(\mathrm{F}_{\text {test }}\right)$, it is known that $\mathrm{F}_{\text {count }}$ is 9.645 while

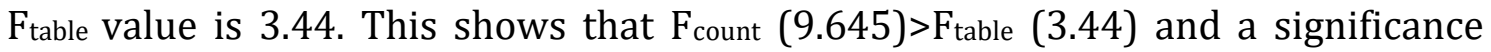
level of $0.001<0.05$. The test results show that the significance value of the simultaneous test $\left(\mathrm{F}_{\text {test }}\right)$ is 0.001 , thus the significance value obtained is smaller than the assigned $\alpha$ probability $(0.001<0.05)$. Therefore, $\mathrm{H}_{0}$ is rejected and $\mathrm{H}_{\mathrm{a}}$ is accepted. It can be concluded that, there is an influence of parenting and thematic learning of friendship on the social ethics of students of Vihara Dewi Kwan Im of North Kayong High School in 2020 with a significance value of 0.001 . When viewed

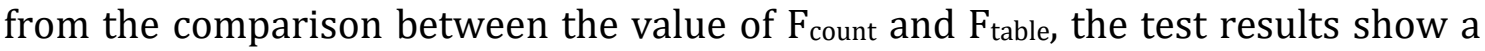
positive effect. The test result indicates the parenting styles variable and the learning thematic friendship at the same time (simultaneously) affect the social ethics of the students of the Buddhist Sunday School at Vihara Dewi Kwan Im of North Kayong in year 2020.

Based on the regression test and the $\mathrm{F}_{\text {test, }}$ it can be concluded that the styels of parenting and thematic learning of friendship simultaneously has a positive influence on the social ethics of the students of Vihara Dewi Kwan Im Kayong North High School in 2020 with a level of influence reaching $46.7 \%$ and is in the sufficient category. The results of these studies are in accordance with the research (Sofia \& Adiyanti, 2014) that the parenting style and similar age peer conformity 
simultaneously relate with the moral intelligence of adolescents with the effect reaching $51.8 \%$.

\section{Discussion}

Based on the research results, there are interesting findings that deserve to be a theme for further discussion,as follows: (a) the influence of parenting styles on social ethics, both social and social among students of the Buddhist Sunday School is not much different from the results of other studies; (b) the effect of thematic learning in this case is similar aged peer interaction, there is a difference where the influence of similar aged peers on the social ethics of students is generally quite large, while the influence of peer interaction on the social ethics of students of the Buddhist Sunday School is relatively small; and (c) the influence of parenting and thematic learning in the context of peer interaction on the social ethics of the Buddhist Sunday School students does not reach 50\%, this is different from the social ethics of students in public schools, where some studies show that the influence is quite large above $50 \%$.

This phenomenon can be assumed because there are several things that need to be considered (1) the intensity of the Buddhist Sunday School activities is relatively minimal, only once a week, compared to public schools can affect the association of the Buddhist Sunday School students; (2) the application of the Buddhist Sunday School learning curriculum is not optimal; and (3) the cultivation of Buddhist social ethics in the Buddhist Sunday School environment has not occurred optimally.

\section{Conclusion}

Based on the results of the study, it can be concluded that: (1) parenting has a positive influence on the social ethics of students at Vihara Dewi Kwan Im of North Kayong High School. This proves that the role of parents is very important in ethical education for children. This study found that the parenting styles adopted by the students' parents were mostly democratic parenting; (2) the thematic learning of friendship has a positive influence on the social ethics of students at the Buddhist Sunday School at Vihara Dewi Kwan Im of North Kayong High School. This proves that the theme of friendship in the Buddhist Sunday School curriculum is very relevant to building the character of the Buddhist Sunday School students, in this case, students' social ethics; (3) parenting patterns and thematic learning of friendship have a positive influence on the social ethics of students at Vihara Dewi Kwan Im of North Kayong High School. Parenting is more dominant than friendship thematic learning. This indicates that if good parenting and the thematic learning application of friendship in the Buddhist Sunday School curriculum are implemented optimally, the social ethics of students can develop well.

Based on the results of this study, it can be suggested that to parents to be able to apply good parenting to improve social ethics; to high school students, in particular, to be apply the values of good friendship (kalyānamitta) in everyday relationships; to Buddhist Sunday School teachers should be able to implement 
thematically-based Buddhist Sunday School curriculum optimally so that they can build a holistic student character.

\section{Acknowledgements}

Researchers would like to thank all those who support and are involved in this research. Thanks to all lecturers and staffs of Smaratungga Buddhist College, the people of the Dewi Kwan Im Temple and the Buddhist Sunday School students who actively participated and all those who cannot be named one by one.

\section{References}

Alhadabi, A. (2019). Modeling parenting style, moral intelligence, academic selfefficacy and learning motivation among adolescents in grades 7-11. Asia Pacific Journal of Education, 39(1), 133-153. doi: 10.1080/02188791.2019.1575795.

Alonso-Stuyck, P. (2019). Which parenting style encourages healthy lifestyles in teenage children? prposal for a model integrative parenting styles. International Journal of Environmental Research And Public Health, 16(2057), 1-7. doi: 10.3390/ijerph16112057

Itivuttaka. (2000). Tranlated by P. Masefield, Penerj. London: The Pali Text Society. Good, L. (2000). Kamus Filsafat. Jakarta: Gramedia.

Barnawi, \& Arifin. (2012). Etika dan Profesi Pendidikan. Yogyakarta: Ar-ruzz Media.

Baumrind, D. (1966). Effects of authoritative parental control on child behavior. Child Development, 37(4), 887-907. doi: 10.2307/1126611

Bertens, K. (2002). Etika. Jakarta: PT. Gramedia Pustaka Utama.

Buddhadatta. (1989). English-Pali Dictionary. Delhi: Mortilal Banarsidas.

The Path of Purity (Visudhi Magga). (1975). Translated by R. Davids. London: The Pali Text Society.

Dariyo, A. (2011). Psikologi Perkembangan Anak Tiga Tahun Pertama. Bandung: PT. Refika Aditama.

Darling, N., \& Steindberg, L. (1993). Parenting style as context: an integrative model. Psychological Bulletin, 113(3), 487-496. doi: 10.1037/00332909.113.3.487

Dialogues of The Buddha (Digha Nikaya) Vol. III. (1977c). Translated by R. Davids, . London: The Pali Text Society.

Dialogues of The Buddha (Dhiga Nikaya) Vol. II. (1977b). Translated by R. Davids. London: The Pali Text Society.

Djamarah, S. (2014). Pola Asuh Orang Tua dan Komunikasi dalam Keluarga. Jakarta: PT. Rineka Cipta.

Emzir. (2015). Metodologi Penelitian Pendidikan Kuantitatif dan Kualitatif. Jakarta: Rajawali Press.

Endraswara, S. (2010). Etika Hidup Orang Jawa. Jakarta: Narasi.

Feriandi, \& Marzuki. (2016). Pengaruh Peran Guru PPKN dan Pola Asuh Orang Tua Terhadap Tindakan Moral Siswa. Jurnal Kependidikan UNY: Penelitian Inovasi Pembelajaran, 46(2), 193-206.

Gunarsa, Y., S, \& Gunarsa, S. (2012). Psikologi Remaja.. Jakarta: Libri. 
Harvey, P. (2000). An Introduction to Buddhist Ethics: Foundations, Values and issues. Cambride: Cambride University Press.

Lorence, BV-P. (2019). The role of parenting styles on bebavior problem profiles of adolescents. International Journal of Environmental Research and Public Health, 16(2767), 1-17. doi: 10.3390\%2Fijerph16152767

Madjid, A. (2014). Pembelajaran Tematik Terpadu. Bandung: Remaja Rosda Karya.

Encyclopedia of Buddhism Vol. V. (1990). Malalasekera, G. (Ed.). Ceylon: The Government of Ceylon.

Raxsa, Yatno, \& Wardani. (2018). Pengaruh Lingkungan sosial dan pola asuh orang tua terhadap moral remaja buddhis di Kecamatan Ponggok Kabupaten Blitar. Jurnal Pendidikan, Sosial, Sains dan Agama, 4(2), 59-69.

Sartika \& Daulay. (2014). Pola asuh orang tua dan perkembangan sosialiasi remaja di SMA Negeri 15 Medan. Jurnal Keperawatan Holistik, 1(1), 40-46.

Sarumpaet. (2006). Etika Bergaul. Bandung: Indonesia Publishing House.

Khuddakapatha. (1978). Translated by Smith, H. London: The Pali Text Society.

Sofia, \& Adiyanti. (2014). Hubungan pola asuh otoritatif orang tua dan konformitas teman sebaya terhadap kecerdasan moral. Jurnal Pendidikan Progresif, 4(2), 133-141.

Stewart, A., \& Koch, J. (1983). Children Development Through Adolescene. Canada: John Wiley \& Sons.

Sulaiman. (2018). The Awakened Parenting: Panduan Pendidikan Keorangtuaan Terhubung dengan Program Sekolah Minggu Buddha. Jakarta: Ditjen Bimas Buddha Kementerian Agama Republik Indonesia. (2019). Model Evaluasi Sekolah Minggu Buddha (SMB). Boyolali: STIAB Smaratungga Press.

Sulton. (2016). Realitas pendidikan nilai di lingkungan keluarga, sekolah dan masyarakat. Jurnal Dimensi Pendidikan dan Pembelajaran, 5, 38-48.

Sunarti, E. (2004). Mengasuh dengan Hati, Tantangan Yang Menyenangkan. Jakarta: Elex Media Komputindo.

Susanto \& Aman. (2016). Pengaruh pola asuh orang tua, pergaulan teman sebaya dan media televisi terhadap karakter siswa SMP. Jurnal Pendidikan IPS, $3(2), 105-111$.

The Books of Gradual Sayings (Anguttara Nikaya) Vol. II. (1989). Translated by Woodward. Oxford: The Pali Text Society.

The Books of Kindred Sayings (Samyutta Nikaya) Vol. V. (1989). Translated by F. Woodward. London: The Pali Text Society.

The Groups of Discourses (Sutta Nipata).(2001). Translated by Norman. Oxford: Pali Text Society.

The Middle Length Sayings (Majjhima Nikaya) Vol. I. (1987). Translated by I. Horner. London: The Pali Text Society.

Tim Penyusun. (2017). Kurikulum Pendidikan Keagamaan Buddha : Sekolah Minggu Buddha (SMB). Jakarta: Ditjen Bimas Buddha Kementerian Agama Republik Indonesia.

Triningtyas, Muhayati, S., \& Ariswati, D. (2016). Pengaruh pola asuh orang tua dan interaksi teman sebaya terhadap remaja akhir shaum kifarat. Jurnal Bimbingan dan Konseling, 4(2), 234-251. 
Umar \& Hidayanti. (2014). Peran teman sebaya terhadap pembentukan moral siswa di SMP Negeri 5 Pare-pare. Jurnal Pemikiran, Penelitian Hukum, Pendidikan Pancasila dan Kewarganegaraan, 1(3), 35-40. 